\title{
Profitability of Resettled Farmers' Crop Production Enterprise in Yauri Emirate, Kebbi State Nigeria
}

\author{
Umar, $S^{1}$., ${ }^{1}$ H.B. Birnin-Yauri ${ }^{2}$, and ${ }^{1}$ A. Gona \\ ${ }^{I}$ Department of Agricultural Economics and Extension, Faculty of Agriculture, Kebbi State University of \\ Science and Technology, Aliero. \\ ${ }^{2}$ Department of Agriculture, College of Basic and Applied Studies, Yelwa Yauri, Kebbi State, Nigeria.
}

\begin{abstract}
This study determines the Profitability of resettled farmers' crop production enterprise in Yauri Emirate, Kebbi State Nigeria. The study was conducted in the 3 Local Government Areas of the Emirate. Purposive sampling was used to select twelve villages in the LGAs (4 villages/ LGA). Ten resettled farmers were randomly selected from each village and questionnaires administered to each of them to obtain a total of 100 respondents. Descriptive statistics and farm budgeting techniques were used for the data analysis. The results of the study shows that crop production in the study area is characterized as subsistence by majority of the respondents (79.2\%), and the land tenure practiced by farmers are renting (40.8\%) and sharecropping (25.0\%). The cost of transportation of the farm produce/tonnage was found to be exorbitantly high and increasing seasonally according to the respondents. Majority of the respondents (40\%) of the respondents confirmed that they pay between $\mathrm{N} 2000$ and N 3000, 54\% pay between N3001 and N4000 and remaining 6\% pay above N4001.. $24.2 \%$ of the respondents recorded a negative net farm income (loss) on crop production enterprise during the season under review and the expenditure on variable inputs accounted for $98.50 \%$ of the total cost of crop investment.
\end{abstract}

\section{Introduction}

Displacement or the involuntary and forced relocation of people has come to be acknowledged as among the most significant negative impacts of large water resource development projects such as dams. It is estimated that nearly 60 million people have been displaced worldwide due to the reservoirs created by large dams (McCully, 1996). A World Bank review of 192 projects worldwide for the period 1986 and 1993 estimated that 4 million people were displaced annually by the 300 large dams (on an average) that entered into construction every year. All these figures are at best only careful estimations and certainly do not include the hundreds of thousands and millions who may have been displaced due to several others aspects of the projects such as canals, powerhouses, associated compensatory measures such as bio-reserves, etc (Leopoldo et al., 2000).

The Kainji hydroelectric dam project was Nigeria's largest project in the 1962-68 National Development Plans, which was completed in 1968. Kainji dam is 136 kilometers long and 24 kilometers at the widest section with a surface area of 1.25 million square meters and a storage capacity of 15 billion cubic meters, of which the useable storage is 11.5 billion cubic meters of water. (Hybrid Design Associate Environmental Consultants, 2002). Resettlement in developing countries generates a lot of conflicts, because the potentials of many resettlements have not been adequately and properly utilized. The success in relocating the people in each case basically stems from the political power vested to the resettlement authorities to execute the exercise, because those resettled are usually rural and powerless communities. It does happen at times that the resettled people are placed in a position where they cannot raise many objections (Umar, 2008). The phenomenon of population displacement or involuntary resettlement of people has increasingly come to be seen as the most serious social impact/consequences of large dams. The displaced people form one of the sub-groups among the project-affected people. The term displaced is meant to cover a wide range of groups negatively affected by the project. In recent years, worldwide experience with involuntary resettlement have been extensively reviewed, and analysis of existing research shows that in certain projects most of the displaced people were left excessively aggrieved (Carnea, 1996) while in others, certain groups among the displaced end up poorer and more marginalized than others (Scudder, 1997).

The concept of programming resettlement as development programme mode is gaining currency though practice is limited. The record indicates that in those cases in which compensation packages were negotiated with resettled households and other stakeholders, the process has resulted in better outcomes for the resettlement process as a whole. Even when, for whatever reason, the negotiated form of compensation proves not to be the most appropriate or effective option, affected people tend to feel more satisfied, as a result of the negotiation process, as attested by the Zimapan resettlement programme in Mexico (Leopoldo et al., 2000). 
Hybrid Design Associate Environmental Consultants, (2002) reported that some of weaknesses of Kainji dam resettlement scheme that causes resource use conflicts in the area include inadequate legal and regulatory instrument used in implementation of resettlement, the lack of institutional learning to deal with complexity of the conflict that follows resettlement; lack of opportunities for restoring and improving living standards; lack of political will on the part of government; and lack of a number of procedural and financial aspects. This paper attempts to synthesize the profitability of the Kainji dam resettled farmers' production enterprise. Attempt has been made to account for the diverse range of their production experiences.

\section{Methodology}

Yauri Emirate comprises of three Local Government Areas, namely Yauri with headquarters at Yelwa, Ngaski with headquarters at Wara and Shanga with headquarters at Shanga. The area falls within about $80 \%$ of the total area of the Kainji lake. It is located on latitudes $11^{0} 15^{1}-12^{0} 30^{1} \mathrm{~N}$ and longitudes $5^{0} 18^{1}-11^{0} 20^{1} \mathrm{E}$. It has a minimum temperature of $32^{\circ} \mathrm{C}$, which occurs in December during harmattan. The highest mean daily temperature of $39^{\circ} \mathrm{C}$ occurs in March and April (Yauri Meteorological Station, 2012). The Emirate has a population of The Emirate has a population of 353,808 people. Out of this figure 100,564 reside within Yauri local Government LGA, while 127,142 and 126,102 were found in Shanga and Ngaski LGA respectively (National Population Commission, 2012).

Purposive sampling was used to select twelve villages in the LGAs (4 villages/ LGA). Ten farmers were randomly selected from each village to obtain a total of 100 respondents. Descriptive statistics and farm budgeting techniques were used for data analysis

\section{Results and Discussion}

The result of the study further indicated that different land tenure system evolved in the study area as results of continuous shrinking of available land for agricultural production in the study area. Table 1 indicated that the major land tenure practiced by farmers in the study area are renting (40.8\%) and sharecropping $(25.0 \%)$.

Table 1: Distribution of Respondents According to Type of Land Tenure Practice

\begin{tabular}{llll}
\hline Type of land tenure & Frequency & Percentage & Cumulative percentage \\
\hline Inherited & 11 & 9.2 & 9.2 \\
Purchased & 8 & 6.7 & 15.8 \\
Rented & 49 & 40.8 & 56.7 \\
Communal & 11 & 9.2 & 65.8 \\
Borrowed & 11 & 9.2 & 65.8 \\
Sharecropping & 30 & 25.0 & 100.0 \\
Total & $\mathbf{2 4 0}$ & $\mathbf{1 0 0 . 0}$ & \\
\hline
\end{tabular}

Source: Field survey 2010

Discussion with the respondents revealed that in the 80 's, the communities that possess land for cultivation do not charge fees or make agreement to collect certain portion of the farm produce at the end of the season. The farmers added that they began to collect money as rent or portion of the farm produce for the use of the farmland in the early 90's when court cases became rampant as results of the claiming of the borrowed lands by the migrant farmers.

From the Table 2, the distance covered by the farmers on the daily journey to farm from their various houses was presented. Only $26.7 \%$ of the respondents have their farms within 1-16 KMs and 50.8\% covered an average distance of $17-44 \mathrm{KMs}$ before reaching their farms. By the time the farmers trekked/travel to their various farms they have become exhausted as explained by the respondents while more precious time and energy are wasted and lost which could have been used for other meaningful activities. However, the remaining $22.5 \%$ of the respondents reported that they usually migrate to neighboring villages in Kontagora and Borgu emirates in Niger State and Gwandu emirate in Kebbi State, to settle during the rainy season for crop production. Communities that had to cross the Kainji dam to convey their harvested farm produce to their farms also expressed feeling of dissatisfaction on the difficulty they went through. The farm produce are usually offloaded by reaching the dam side and chattered a canoe that will convey the produce to the other side of the river, so that it will be transported again to their houses. This makes the cost of transportation to be highly exorbitant. The facts that these harvested farm produce are not usually processed in the farm (for example guinea corn in bundles and maize in pods) also caused an increase in the cost of transportation. 
Table 2: Distribution of Farmers based on the distance of farm location to the point of storage/sale of farm produce

\begin{tabular}{lrrc}
\hline Distance in km & Frequency & Percentage & Cumulative percentage \\
\hline $1-8$ & 18 & 15.0 & 15.0 \\
$9-16$ & 14 & 11.7 & 26.7 \\
$17-24$ & 17 & 14.2 & 40.9 \\
$25-32$ & 21 & 17.5 & 58.4 \\
$33-40$ & 23 & 19.1 & 77.5 \\
More than 40 & 27 & 22.5 & 100.0 \\
Total & $\mathbf{2 4 0}$ & $\mathbf{1 0 0 . 0}$ & \\
\hline
\end{tabular}

Source: Field survey 2011

According to the results of the study in table 3, the costs of transporting the farm products were also discovered to be considerably high and increasing seasonally according to the respondents. Majority of the respondents (40\%) of the respondents confirmed that they pay between $\mathrm{N} 2000$ and $\mathrm{N} 3000$, 54\% pay between N3001 and N4000 and remaining 6\% pay above N4001. Discussion with the farmers revealed that as a result of high cost of transportation incurred by them, some farmers resorted to pursue land for farming within their proximity through an illegitimate means. Conflicts therefore engendered when the local community or land owners resist the claim of their land by the migrant farmer. Idachaba (1980) in his study of food production problems in the rural areas contended that transportation among other factors represents the most serious constraint to agricultural product and development in Nigeria.

Table 3: Distribution of Respondents according to Cost of Transportation of Farm Produce/Tonne $(\mathbf{n}=120)$

\begin{tabular}{|c|c|c|c|}
\hline Cost of Transport/Tone (\#) & Frequency & Percentage & Cumulative percentage \\
\hline $2,001-3,000$ & 48 & 40.0 & 40.0 \\
\hline $3,001-4,000$ & 58 & 48.3 & 88.3 \\
\hline$>4,000$ & 14 & 11.7 & 100.0 \\
\hline Total & 120 & 100.0 & \\
\hline
\end{tabular}

Source: Field survey 2011

From the results in table 4, it could be observed that majority of the farmers in the study area (53.4\%) are peasant possessing a farm land with sizes ranging from $<1.0-2.0$ hectares.

Table 4: Distribution of Farmers According to Size of Farm Land

\begin{tabular}{llll}
\hline Farm size & Frequency & Percentage & Cumulative percentage \\
\hline$<1.0$ & 38 & 31.7 & 31.7 \\
$1.1-2.0$ & 26 & 21.7 & 53.4 \\
$2.1-3.0$ & 35 & 29.1 & 82.5 \\
$3.1-4.0$ & 16 & 13.3 & 95.8 \\
More than 4.0 & 5 & 4.2 & 100.0 \\
Total & $\mathbf{1 2 0}$ & $\mathbf{1 0 0 . 0}$ & \\
\hline
\end{tabular}

Source: Field survey, 2011

Ogunsumi, (2004) similarly reported that most of the agricultural farms in the resettled communities are on small-scale cultivation varying from 0.1 to 10 ha, making the farmers peasant in nature. Despite Nigerian's enormous resources for agricultural production most especially land, a close look at the agricultural landscape reveals that activities in the food crop sub-sector are continuously dominated by production on several small and scattered landholdings (Olayide et al, 1980).

As revealed from the table 5, 24.2\% of the respondents recorded a negative net farm income (loss) on crop production enterprise during the season under review. The results also indicated that majority of the respondents generate N0-6400 per season, which imply that the crop enterprise did not provide a reasonable income for the farmer during the season. Studies by Acreman et al.(1999), have similarly reported that food crop farmers in developing countries in general and particularly in Nigeria, have low productivity because of the impacts of dams on livelihood strategies of some communities in Africa.

Table 5: Distribution of Farmers According to Net Farm Income per Season

\begin{tabular}{lrrr}
\hline Net Farm Income/ha/season & Frequency & Percentage & Cumulative percentage \\
\hline$-6,400-0$ & 29 & 24.2 & 24.2 \\
$0-6400$ & 48 & 40.0 & 64.2 \\
$6401-12800$ & 20 & 16.7 & 80.8 \\
$12801-19200$ & 14 & 11,7 & 92.5 \\
$19201-25600$ & 6 & 5.0 & 97.5 \\
Total & $\mathbf{1 2 0}$ & $\mathbf{1 0 0 . 0}$ & \\
\hline
\end{tabular}


The result of the study in the table 6 indicates that the selected farmers for the study had a minimum of 6 years experience and a maximum of 60 years with the mean of 33.49 years and standard deviation of 13.389 , which signify that the years of experience of the experience cluster around the average. The result also shows that the farmers travel a minimum of $1 \mathrm{KM}$ and maximum of $116 \mathrm{KMs}$ with the mean of $58.5 \mathrm{KMs}$ to reach their farm from their houses and standard deviation of 24.013 which also signify that the distance travel from farm to farmers' houses cluster around the average. The minimum net farm income of the farmers was found to be N27201/ha/season (indicating a loss) and a maximum of N31, 964 with a mean of N5016.35 and standard deviation of N8928.093, signifying that the net farm income did not cluster around the average.

The cost and revenue structure of the crop enterprise of the farmers are presented in the table 6 . The results indicate that expenditure on variable inputs accounted for $98.50 \%$ of the total cost investment of the crops. This finding agrees with those of Tarfa (1990); Martin (1997) and Dogon Daji (2005) cited in Abbas (2008) who noted that in most subsistence farming systems, variable cost dominates the expenditure accounting for over $90 \%$ of the total cost. The results of the study also shows the average Gross Margin/ha/season and Net Farm Income/ha/season recorded by the farmers were 546.04 and 326.57 respectively. This shows that the average net NFI and GM for the crop enterprise of the farmers during the year under review were found to be low. Idowu and Oladeebo, (1999) attributed the low level of crop production in Nigeria to lack of individual responsibility on farmlands, farmland fragmentation leading to scattering of plots, little incentive for improvements, lack of security of tenure, restricted scale of operations, high cost of transportation of the crop produce and problems encountered in obtaining credit etc.

Table 6: Distribution of Farmers According to Cost Incurred and Revenue Generated on Crop Enterprise

\begin{tabular}{llll}
\hline Variable input & Cost/ha/season & \% of Total Variable Cost & \% of Total Cost \\
\hline Land rent & $3,512.11$ & 3.81 & 3.75 \\
Land preparation & $15,756.10$ & 17.10 & 16.84 \\
Seeds & $1,25.70$ & 1.98 & 1.95 \\
Herbicides & $5,699.96$ & 6.19 & 6.09 \\
Pesticides & $1,615.52$ & 1.75 & 1.73 \\
Fertilizer & $18,498.29$ & 20.07 & 19.77 \\
Organic manure & $1,500.31$ & 1.63 & 1.60 \\
Labor & $28,039.84$ & 30.43 & 29.97 \\
Transport & $15,698.34$ & 17.04 & 16.78 \\
Total variable cost & $92,146.17$ & 100.0 & 98.50 \\
Fixed cost & $1,402.79$ & & 1.50 \\
Total cost & $93,548.96$ & & 100.0 \\
Total revenue & $94,095.25$ & & \\
Gross margin/ha. & 546.04 & & \\
Net Farm Income/ha & 326.57 & & \\
\hline
\end{tabular}

\section{Conclusion and Recommendation}

The paper concludes that a .successful resettlement with development is a fundamental commitment and responsibility of the State. No development project can result in complete alienation of the rights, customary and legal, of people through payment of a one-time compensation or facilitated relocation. On the contrary, the process must result in the creation of new rights that will render people direct beneficiaries of the development project. Just as displacement is not an inevitable consequence of infrastructure development, resettlement need not necessarily result in impoverishment. Central to positive resettlement and rehabilitation will be the empowering of people. The study therefore recommends that the Federal Government of Nigeria should revisit the Kainji dam resettlement exercise, and identify with the communities their needs for production and conservation, as well as constraints faced by them. Local communities usually have sound ideas and workable solutions but lack the means and technical support to implement them. This will provide the means of addressing the production problems of the farmers.

\section{References}

[1]. Acreman, M. et al. (1999) Managed flood releases from reservoirs: a review of current problems and future prospects, Institute of Hydrology, Oxford. 16pp

[2]. Carnea, M. (1996). Understanding and preventing impoverishment from displacement: Reflections on the State of Knowledge. Colorado, West View press. P.I. 32pp

[3]. Dogondaji, S.D. (2005). Economics of dry season onion production and marketing in Sokoto and Kebbi States. Unpublished PhD Thesis Submitted to the Department of Agricultural Economics and Extension, Faculty of Agriculture, Usmanu Danfodiyo University, Sokoto, Nigeria. 121-122

[4]. Hybrid Design Associates Environmental Consultants, (2002). Socioeconomic and environmental impact study of Kainji Hydroelectricity dam on Yauri Emirate. Unpublished report submitted to Yauri Emirate council committee on HYPPADEC, Yauri. Pp.1-45.

[5]. Idachaba F. (1980), 'The Green Revolution: A Food Production Plan for Nigeria'.Final Report submitted to the Federal Ministry of Agriculture. 61pp. 
[6]. Idowu, F.O., and Oladeebo J.O., (1999). The effects of scattered farm plots on agricultural production in the Guinea savannah zone of Oyo State, Nigeria. Journal of Rural Economics and Development, 13: 103-110.

[7]. Leopoldo J. B. Chris de W., Harsh M., and Vijay K.M. (2000). Displacement, Resettlement, Rehabilitation, Reparation, and Development. Final Version: November 2000 Prepared for the World Commission on Dams (WCD).

[8]. Martins, U. (1997). Economics of Tropical Agriculture. Low Price Edition. Oxford University Press, London. 345 pp. Cited in Abbas, Y.A. (2008). Sustainable Cost Recovery in Kano River Irrigation Project, Nigeria. Unpublished PhD Thesis Submitted to the Department of Agricultural Economics and Extension, Faculty of Agriculture, Usmanu Danfodiyo University, Sokoto, Nigeria. 47pp.

[9]. McCully, Patrick. 1996. Silenced Rivers: the Ecology and Politics of Large Dams, London, Zed Books.[10].National Population Commission, (2012). Report on 2012 Population census, Kebbi State, Nigeria. 33pp.

[11]. Ogunsumi, L.O. (2004) Analysis of Sustained use of Agricultural Technologies on Farmers' Productivity in Southwest Nigeria, Unpublished Ph.D. Thesis, Federal University of Technology, Akure,Nigeria. 199-200.

[12]. Olayide, S. O. Eweka, J.A. Bello Osagie V. E. (Eds) (1980), "Nigeria Small Farmers Problems and Prospects in integrated Rural Development. 99pp.

[13]. Scudder, T.(1997). Chapters on Social Impacts and Resettlement in Water Resources: Environmental planning, Management and Development, New York P. 1-2.

[14]. Tarfa, S.B. (1990). An economic analysis of factors affecting small-scale dry season irrigation farming: A case study of DadinKowa area of Bauchi State. Unpublished MSc Thesis, Department of Agricultural Extension and Rural Sociology, A.B.U. Zaria. 79pp. Cited in Abbas, Y.A. (2008). Sustainable Cost Recovery in Kano River Irrigation Project, Nigeria. Unpublished PhD Thesis Submitted to the Department of Agricultural Economics and Extension, Faculty of Agriculture, Usmanu Danfodiyo University, Sokoto, Nigeria. 128pp.

[15]. Umar, S. (2008). A Study of Socio-economic Impact of Kainji Hydroelectricity Dam Project in Yauri Emirate, Kebbi State Nigeria. Unpublished MSc Dissertation Submitted to the Department of Agricultural Economics and Extension, Faculty of Agriculture, Usmanu Danfodiyo University, Sokoto, Nigeria. Pp97-98.

[16]. Yauri Meteorological Station (2012). National Meteorological Agency, Kebbi State. 13pp. 